\title{
Human Security as Final Cause of Political Society ${ }^{*}$
}

\author{
Siyâsî Toplumun Nihâî Nedeni Olarak İnsan Güvenliği
}

\author{
Hakkı Hakan Erkiner iD, Emerant Yves Omgba Akoudou (iD
}

\section{öz}

1990’larda uluslararası ilişkilerde ortaya çıkışıyla beraber insan güvenliği kavramı akademik ve siyasi çevrelerde büyük ilgi uyandırmıștır. Çeşitli teoriler ortaya atılmış ve bu kavrama somut şekil verilmiştir. Bu tartışma hala devam etmektedir çünkü insanın güvensizliği dünyanın herhangi bir yerinde günlük bir deneyim olmaktan hala çıkmadı, bu da teori ile gerçeklik arasında belirli bir boşluğa işaret edebilir. $\mathrm{Bu}$ makale, insan güvenliğinin anlaşılmasına ve bunun siyasi topluma ilişkin memnuniyetinin genel anlamına bir katkı sağlamayı amaçlamaktadır. Kesin olarak, özcü bir bakış açısıyla, kendisini bir doğa kanunu olarak sunduğu natüralist bir insan güvenliği anlayışı ileri sürmektedir. Dolayısıyla insan güvenliği, kaçınılmaz olarak korumayı içeren doğal insan düzenini somutlaştırmaktadır. Bu doğal gereksinimi karşılama ihtiyacıyla, insan güvenliği, siyasal toplumun (doğal) kanun, yani siyasal toplumun nihai nedeni veya temeli ve amacı olarak sunulmaktadır. Böylelikle, insan güvenliğinin natüralist anlayışı, insanın politik hayvansallığının ve sözleşmesel felsefelerin yeni okumalarının temelidir.

Anahtar Kelimeler: İnsan Güvenliği, Siyasal Toplum, Nihai Neden, Doğa Kanunu, İnsanın Doğal Düzeni

\section{ABSTRACT}

Since its emergence in international affairs in the 1990s, the concept of human security has aroused great interest in academic and political circles. Various designs have been put forward and given concrete form. This debate continues because human insecurity has not ceased to be a daily experience somewhere in the world, which can also signal a certain gap between theory and reality. This article is a contribution to the understanding of human security and the general meaning of its satisfaction in relation to political society. Precisely, from an essentialist perspective, he puts forward a naturalist conception of human security, by which it presents itself as a law of nature. Thus, human security is understood to embody the natural human order inevitably involving conservation. By the need to satisfy this natural requirement, human security is presented as the (natural) law of political society, that is to say the final cause, or the foundation and the finality of political society. . Thus the naturalist conception of human security is the basis of new readings of the political animality of man, and of contractualist philosophies.

Keywords: Human Security, Political Society, Final Cause, Law Of Nature, Human Natural Order

* This article has been produced from PhD thesis named "Human Security and International Law"

** Assoc. Prof. Dr., Marmara University Faculty of Law Department of International Law

*** PhD. in Public Law, emerant.akoudou@marun.edu.tr

Sorumlu Yazar/Correspondence Author: Hakkı Hakan Erkiner

E-posta/E-mail: herkiner@marmara.edu.tr

Geliş Tarihi/Received: $\quad 31.12 . .2020$

Kabul Tarihi/Accepted: $\quad$ 15.01.2021 


\section{INTRODUCTION}

The concept of security in international relations has evolved from a state-centered to an individualcentered model. After the treaties of Westphalia, the international arena was considered as an umbrella entity with states, as natural components. Consequently, peace in this space was envisaged only in terms of state security and therefore of protection of the sovereignty of States. This state of affairs went through the two world wars and continued until the end of the Cold War. Although the international care of the concerns of the individual has been enshrined in the United Nations Charter and subsequent human rights instruments, human security has emerged as an international concern over the years 1990. Indeed, the attention of insecurity has unequivocally shifted from States to individuals. It was no longer just a question of states threatened from outside by others, but also of civilian populations threatened during internal crises either by their rulers, or by organized armed groups or by nature. International Peace and Security has thus been extended to individuals. Indeed, by numerous Resolutions, the United Nations Security Council authorized interventions in Iraq, in Bosnia as well as in Somalia in order to protect the dignity of populations seriously affected by repression. Before the publication of the 1994 United Nations Development Program (UNDP) Report on Human Development, the momentum for human security was evident. So this report came to echo this trend. Until then human security has been the subject of an abundant thinking process.

Generally, there are three approaches or conceptions of Human Security: broad, restricted and hybrid. According to the broad conception, human security includes all threats endangering the well-being of individuals. It emphasizes human vulnerability in all its dimensions and therefore encompasses threats of all kinds without taking into account the degree of severity. The broad view is about protecting the vital essentials of every human being and therefore guaranteeing them a life free from want and fear. This would tend to bring it closer to the concept of human development. ${ }^{1}$ The narrow view does not embrace all possible threats to human security, but focuses on the most violent threats, particularly organized political violence. ${ }^{2}$ Supporters of this conception of Human Security

1 PROGRAMME DES NATIONS UNIES POUR LE DEVELOPPEMENT, Rapport mondial sur le développement humain 1994, Paris, Economica, Chapitre 2 intitulé "Les nouvelles dimensions de la sécurité humaine”, 1994; NATIONS UNIES ASSEMBLEE GENERALE, Résolution adoptée par l'Assemblée générale le 10 septembre 2012 [sans renvoi à une grande commission A/66/L.55/Rev.1 et Add.1)] A/RES/66/290 66/290, Suite donnée au paragraphe 143 sur la sécurité humaine du Document final du Sommet mondial de 2005, 25 octobre 2012; UNITED NATIONS GENERAL ASSEMBLY, Resolution adopted by the General Assembly on 10 September 2012 [without reference to a Main Committee (A/66/L.55/Rev.1 and Add.1)], Follow-up to paragraph 143 on human security of the 2005 World Summit Outcome, A/RES/66/290 66/290, 25 October 2012; COMMISSION ON HUMAN SECURITY, Human Security Now: Final Report, New York, Commission on Human Security, 2003; FUKUDA-PARR Sakiko, MESSINEO Carol, Human Security: A critical review of the literature, Centre for Research on Peace and Development, Working Paper n. 11, KU Leuven, January, 2012; NEF Jorge, "Human Security, Mutual Vulnerability and Sustainable Development: A Critical View", The Whitehead Journal of Diplomacy and International Relations, vol. 7, n. 1, Winter-Spring 2006, pp. 55-73; LEANING Jennifer, ARIE Sam, Human Security: A Framework for Assessment in Conflict and Transition, Prepared for US AID, Tulane Complex Emergency Response and Transition Initiative (CERTI), Tulane University, December 2000; ACHARYA Amitav, "Human Security: East versus West”, International Journal, vol. 56, n. 3, 2001 , pp. 442-460.

2 HUMAN SECURITY NETWORK, http://www.humansecuritynetwork.org/network-f.php (26.03.2021); FUKUDAPARR, MESSINEO, ibid.; AXWORTHY Lloyd, "Human Security and Global Governance: Putting People First”, Global Governance, 2001, vol. 7, n. 1, pp. 19-23. 
defend its immediate operational character in comparison to the broad conception which requires a very long-term strategic development plan. ${ }^{3}$ Finally, the hybrid conception of Human Security aims to reconcile the first two ones on the threshold of gravity. Thus, it would be a matter of giving priority to the most serious threats. Security would therefore aim to deal with threats of a high level of gravity, no matter what area they fall into. ${ }^{4}$ The hybrid view of human security has the advantage of finding a balance between the broad and the narrow ones by determining a criterion that makes human security initiatives more practical.

Following these conceptions, we believe, another understanding of human security is possible, by approaching the relationship it can sustain with political society. Indeed, it is a truism that human security has only its sense within a political society, in which it is supposed to be satisfied. Thus emphasizing in this relationship will shed light on a new way to understand both human security and political society in view of a better satisfaction of the former. Then, we postulate such a relationship is ontological, that is to say, that human security is the final cause of political society.

The meaning of the "final cause" is to be understood from Aristotle who is the first to give an account of it. According to Aristotle, things that exist by nature ${ }^{5}$ are distinguished from other things in that each of them has within itself various principles of change and resistance to change, principles that are intrinsic causes of its formal development (formal causes) and its role in nature (its final cause). Such principles are distinct from the various kinds of things that exist by nature and that are definitive to them: they constitute their essences. ${ }^{6}$ Aristotelian essentialism noted that material things of a given kind distinguish each other by the substances they contain (their material causes); their shapes, sizes, textures (their formal causes), what brings them into existence (their efficient causes), the purposes for which they exist (their ultimate causes). ${ }^{7}$

According to Aristotle the final cause is that for which the thing is or exists. Thus everything has a purpose which grounds its nature. Things exist only for a purpose that accounts for their nature. Final causes essentially have a purpose and the explanations given in these terms are said to be teleological, that is, they account for the purpose for which the thing is what it is. ${ }^{8}$ However, a better understanding of Aristotle requires us to make a difference between his telos and the functional role of things, because the purpose of a thing that exists by nature is never accidental. Indeed, Aristotle

3 LIOTTA Peter Hearns, OWEN Taylor, "Why Human Security?", The Whitehead Journal of Diplomacy and International Relations, vol 7, n. 1, Winter-Spring 2006, pp. 37-54.

4 OWEN Taylor, "Human security. Conflict and Consensus: Colloquium Remarks and Proposal for a Threshold-Based definition", Security Dialogue, vol. 35, n. 3, September 2004, pp. 373-387; ESTRADA-TANCK Elena Dorothy, Human Security and Human Rights under International Law: Crossroads and Possibilities, European University Institute, 2010, http://www.operationspaix.net/DATA/DOCUMENT (26.03.2021).

5 In the Category of things existing by nature one finds animals and their parts, plants and elements from which all terrestrial and celestial bodies are ultimately constituted.

6 ELLIS Brian, The Philosophy of Nature, A Guide to the New Essentialism, Acumen Publishing Limited, Chesham, 2002, p. 10.

7 Ibid.

8 ELLIS, ibid.; TANZELLA-NITTI Giuseppe, "The Aristotelian-Thomistic Concept of Nature and the Contemporary Debate on the Meaning of Natural Laws", Acta Philosophica, n. 6, 1997, p. 8. 
postulates that everything that exists by nature has a telos that belongs to its essence: "Everything which happens either happens by chance or for the sake of an end. Now those things which happen outside the intention of an end are said to happen by chance. But it is impossible for those things which happen in every instance or in most instances to happen by chance. Therefore, those things which happen in every instance or in most instances happen for the sake of something Now whatever happens according to nature happen either in every instance or in most instances, as even they admitted. Therefore, whatever happens by nature happens for the sake of something. (...) Things which happen naturally are done so that they lead to an end. Therefore they are disposed to be done in such a way that they are for the sake of an end. And thus nature seeks an end, i.e. nature has a natural disposition for an end."

Therefore the telos of everything that exists by nature exists independently of everything else. He further postulates that the ultimate goal of all philosophical research is to know the telos of things: the reasons for their existence. In this sense, the final cause is the highest of all causes. ${ }^{10}$ It has to be noted that this apprehension of the concept of final cause is part of Aristotle essentialism, which like most essentialist theories are focused on essential properties of things ${ }^{11}$ focusing on it to give an account of the relationship between human security and political society characterizes our position as essentialist. Indeed, undertaking to give an account of things and their functioning by explaining the intrinsic properties of their most basic constituents is a realistic and scientifically sound approach. Essential properties are unquestionable realities that are the foundation of all things. Therefore it is not a creative work that would depend on the author's subjectivity, but on an objective existent. Thus if we assume that the relationship between human security and political society is ontological, or that the former is the final cause of the latter, we are assuming that human security contributes to an essentialist understanding of political society. Assuming that is certainly informing at the meantime the relationship between human security and human nature, and precisely postulating that human security better gives an account of the human nature. In other words, it is only in the state of security that human nature bears full significance. Human security is thus the consubstantial state of human nature and signifies it in its reality. Human nature is a physical and rational nature. This dual dimension of Man is naturally ordered and functions in its own way and the state of security is the indicator of its order, that is to say, when body and mind are in order and function as they essentially should, Man is in security. Human security thus embodies human nature in its real state. Man is Man only in a state of human security. Thus, in any situation where this nature would be opposed to an order or a state that is contrary to that what is intrinsically required, the resulting state is simply an intolerable insecurity, by the very fact of this nature. So it is not just a matter to be a human being, but to be in security. In our view, reference to the etymological sense should suffice to justify that. Indeed, the word "security" comes from the Latin "securitas" which means "carefree". Thus security refers to a state of absence of suffering or absence of pain. This apprehension of security is negative

9 TANZELLA-NITTI, op. cit. pp. 9-10.

10 ELLIS, op. cit. p. 12.

11 Essentialism "in general may be characterized as the doctrine that (at least some) objects have (at least some) essential properties." ATKINS Philip, "Essential vs. Accidental Properties", Stanford Encyclopedia of Philosophy, First published Tuesday April 29, 2008; substantive revision Monday April 18, 2016, https://plato.stanford.edu/entries/essentialaccidental (26.03.2021). 
in that it emphasizes something that is not. On the contrary, in a positive way, it refers to a state of well-being. This basic definition of security, applied to human nature, captures human security as the essential order of that nature. That way the broad definition of human security from the 1994 UNDP Report which sums up in freedom from fear and freedom from want is in accordance with our postulate because these two components simply signifies a state of human well-being.

This gives sense to the consensually-known natural tendency of man to conservation, early recognized by Aristotle. ${ }^{12}$ According to the Dictionary, conservation is the action of maintaining the same state without any alteration. It is the action of keeping intact, the action of keeping, defending, opposing any change of state. ${ }^{13}$ Thus if human nature is doomed to conservation, it confirms that only the state of security consubstantial to it better accounts for it. That implies for Man is to continue or to remain permanently in this state. This is a confirmation of his nature. Any attitude contrary to conservation could mean only one thing: ruin, which gradually leads to nullity, and the simple cause of this can just be summed up in insecurity.

These considerations allow us, from an essentialist perspective to approach human security, both as the finalized and finalitarian order of human nature. As finalized order, human security is an existent, which does not need to be created, or realized, since it is already real, and it is why it requires conservation. Conservation is only possible related to an existent, for one conserves something that already exists. Furthermore if conservation implies permanence of the thing on which it is about, then it is not everything but precisely that thing, which is in this framework, the sate consubstantial to human nature. As the finalitarian order, human security, is a constant need of human nature, which always require to be confirmed in that. That justifies again then the human natural tendency to remain in that state by conservation.

In this logic, if human security is the final cause of political society, it means that the foundation and finality of political is to simply satisfy or guarantee satisfaction of the human security requirements for each member of the society. It is in this logic that political society works. Relying on human security as the final cause of political society requires that the link between human security and political society be made clear. From an essentialist point of view, in our view, this link is only established on the basis of three kinds of inclusive natural realities: the individual necessity of conservation, the multitude of individuals, and the need for nature's resources for conservation. Thus, humans are obliged to conserve themselves in the presence of a multitude of fellow human beings through the use of nature's resources. On the basis of these three natural requirements, human security as the law of human nature automatically implies that human security is the law of political society. They

12 ABEL Donald, Theories of human nature: Classical and contemporary readings, New York: Mcgraw-Hill, 1992; Loptson P., Theories of human nature, Peterborough: broadview, $3^{\text {rd }} \mathrm{Ed}$. 2006; COURNARI Laurent, "Aristote, Commentaire du livre IV des Politiques”, Philopsis, éditions numérique, http://www.philopsis.fr (26.03.2021); CHENET François Xavier, "KANT, Philosophie pratique, Métaphysique des mœurs, Critique de la raison pratique", Philopsis, éditions numériques, 2008, http://www.philopsis.fr (26.03.2021); NIETZSCHE Friedrich, La volonté de puissance, 2 tomes, Gallimard, Paris, 1995.

13 CENTRE NATIONAL DE LA RECHERCHE SCIENTIFIQUE (CNRTL), Dictionnaire sur PC Ortolang du Centre National de la Recherche Scientifique, comprenant les dictionnaires de l'Académie française jusqu’à la 9ème édition, http://www.cnrtl.fr (31.03.2021). 
make it possible to postulate, in the sense of Aristotle, that man is naturally a political animal. We will explain the meaning of this postulate by referring to Aristotle's conception, but by considering it in the sense of a logical implication of human security. In other words, we will conceive the political animality of man according to the requirements of the law of human security, which will sometimes imply a demarcation from the Aristotelian position and the recourse, when necessary, to reasoning by hypothesis to enable us to better grasp this reality. Thus, human security as the final cause of political society implies conceiving Man's political animality progressively from a natural nature (I) to a cultural nature (II). We will clarify the meaning of these concepts.

\section{MAN'S POLITICAL ANIMALITY: A NATURAL NATURE}

The political animality of man as a natural nature can be an implication of human security as better accounting for human nature. The concept of natural nature means that the natural human order as human security accounts for it, is, in an essentialist point of view, a reality or a state of affairs that is no longer to be realized but to be confirmed in view of its vocation to permanence. In this logic, the natural order and the human experience are more or less in phase. We shall bring this out by dwelling on two substances: the substance of the ontological relationship between human security, and political society (A) and the substance of Man's understanding of that relationship (B).

\section{A. SUBSTANCE OF THE ONTOLOGICAL RELATION BETWEEN HUMAN SECURITY AND POLITICAL SOCIETY}

To account for man's political animality as a natural nature, human security as the final cause of political society is verified as a logical implication of human security as the order of human nature (1) and by the fact of the embryonic society that constitutes the family (2).

\section{Human Security As The Final Cause Of Political Society: A Logical Implication Of Human Security As The Order Of Human Nature}

Human security, in an essentialist point of view, stands as the state that is consubstantial with human nature. It is the essential disposition of human nature, accounting for the natural human order. This state of well-being, implies conservation or confirmation because of its vocation to permanence. That way human security constitutes the foundation and purpose or finality of all human action. That said, if human security is to be conserved, we may rightly assume that conservation cannot be undertaken in all ways, because it would be included in the package of conservation, means that could lead to insecurity. Therefore conservation implies an order of means adequate that could lead to satisfy human security permanently. Thus, according to Johann Gustav Droysen, "Undoubtedly we only understand completely that which is, when we recognize and make clear to ourselves how it came to be. But how it came to be, we recognize only if we investigate and understand, as exactly as possible, how it is. Our grasping that which came to be and comprehending its becoming is only one form and 
expression of our understanding of the present and existing can be derived only by temporally conceiving and analysing the existing in order to understand it." ${ }^{\prime 4}$

It is therefore legitimate to think that nature is a real order whose confirmation is possible through means just as real as it conceals, but up to understanding or discovery of which human nature gradually comes. In this way Cicero asserted: "True law is right reason conformable to nature, universal, unchangeable, eternal, whose commands urge us to duty, and whose prohibitions restrain us from evil. Whether it enjoins or forbids, the good respect its injunctions, and the wicked treat them with indifference. This law cannot be contradicted by any other law, and is not liable either to derogation or abrogation. Neither the senate nor the people can give us any dispensation for not obeying this universal law of justice. It needs no other expositor and interpreter than our own conscience. It is not one thing in Rome and another at Athens, one thing today and another tomorrow, but in all times and nations this universal law must forever reign, eternal and imperishable. It is the sovereign master and emperor of all beings. God himself is its author, its promulgator, its enforcer. And he who does not obey it flies from himself and does violence to the very nature of man. And by so doing he will endure the severest penalties even if he avoids the other evils which are usually accounted punishment." 15

Then, what is the relationship with political society?

The link between human security and political society is raised in consideration of two other equally natural requirements which conservation is undertaken with: conservation is made, among other things, through resources of nature and in the presence of a multitude of human beings. These two realities make human security the final cause of political society.

Human security is the essential disposition of human nature, which happens to be two-dimensional in its unity: a rational dimension and a physical dimension. Immanuel Kant expresses it in both the animal and the rational side. 16 "The animal nature is the mechanical, impulse oriented side of human nature. It seeks the preservation of the self with the goal of maximizing personal pleasure and minimizing pain. In other words, the animal nature is based on sensuous impulses"17 The physical nature of the human being is conserved on the basis of the resources of the physical nature surrounding him. $\mathrm{He}$ is taking everything he needs from it for food, health, shelter and clothing.

The human being is also called to share his life with a multitude of other human beings. Indeed, it is a fact of nature that the human being is not alone. The very conditions of his birth show that he is the fruit of a man and a woman who have been endowed by nature with dispositions enabling them to reproduce or to be perennial or simply to multiply. So whatever the real or hypothetical nature of the origin, including the spatial configuration, of the multitude of human beings populating earth,

14 BARTH Hans, The Idea of Order, Contributions to a Philosophy of Politics, D. Reidel Publishing Company, DordrechtHolland, 1960, p. 1.

15 ALFORD Fred, Narrative, Nature, and the Natural Law. From Aquinas to International Human Rights, Palgrave Macmillan, New York, 2010, p. 22.

16 FRIEDRICH Carl Joachim (Ed.), The Philosophy of Kant: Moral and Political Writings, New York, The Modem Library, 1949, p. 373.

17 KANT Immanuel, The Doctrine of Virtue, trans. of GREGOR Mary, New York, Harper Torchbooks, 1964 , p.10. 
the multitude itself is an undeniable reality. The individual conservation of human security for many individuals through resources of nature has therefore been provided for by nature itself. Since nature is an order and therefore does nothing in vain, ${ }^{18}$ it must be assume that it contains the code of means by which the multitude of cohabiting human beings can, through resources of physical nature, confirm the intrinsic order they are subject to by nature. This code of means is precisely the one that can be known under the generic term "society". So, since the order of human nature is security, then it becomes the final cause of society, understood as the means by which nature allows a set of cohabiting human beings to individually confirm the order to which it has reduced them and which is simply themselves. This code or order of means is therefore real in that without it, the conservation of human security, which is nothing else than the conservation of human nature for each individual cohabiting with others, cannot be adequate.

According to its etymology, society comes from the Roman "societas" referring to association, community, company, meeting, political union, alliance. According to a simple definition, society is a structured and organized grouping of individuals, a group of people brought together by common interests or for a common activity or action. It is a group of people living in an organized and structured way through institutions and conventions. ${ }^{19}$ From this simple apprehension of society, an idea of understanding, agreement, organization or simply order clearly emerges. Hence it emerges that if human security represents the order of human nature, which is no longer to be realized but to be confirmed or conserved in the way it is, it means the order of the human kind and therefore of all human beings who are part of the kind. Nature has thus united human beings around the same condition and the sum of their individual conservation interests makes a common interest of confirmation. So how can we think that nature could have subjected them to and governed them under a condition other than agreement? If nature is already an order in itself, the disorder that would result from misunderstanding or conflict cannot be imputed to it. Thus, society must be thought of or apprehended as essentially natural. It refers more to an understanding, an agreement, an order that governs human beings in the individual purpose of confirmation. And it is this order which is generally understood as "politics". It is generally agreed that the concept of politics comes from the Greek polis meaning "city", the latter being considered the basic unit of political organization in the Greco-Roman world. ${ }^{20}$ Thus, politics meant the art of governing the city or the State. ${ }^{21}$ More precisely, "Politics can be simply defined as the activity by which differing interests within a given unit of rule are conciliated by giving them a share in power in proportion to their importance to the welfare and survival of the whole community." 22

18 SAINT-HILAIRE Jules Barthelemy, La Politique d'Aristote, Traduite en Français d'après le Texte Collationné sur Les Manuscrits et les Éditions Principales, Troisième Édition, Revue et Corrigée, Paris, Librairie Philosophique de Ladrange, 1874.

19 Dictionnaire Encarta, Microsoft ${ }^{\circledR}$ Encarta $^{\circledR}$ 2009. (๑ 1993-2008 Microsoft Corporation.

20 ROBERTSON David, The Routledge Dictionary of Politics, 3rd Ed. Taylor \& Francis Group, Routledge USA and Canada, New Fetter Lane, London, New York, 2004, p. 382.

21 RIMBOUX Elsa, "Politique", Grand Dictionnaire de la Philosophie, Edition numérique, Larousse, Bibliothèque Nationale de France, pour la bibliothèque numérique Gallica, 2003, pp. 2397-2399; SCRUTON Roger, "Politics", The Palgrave Macmillan Dictionary of Political Thought, 3rd edition, Palgrave Macmillan, New York, 2007, p. 550 
It can therefore be concluded that since human security is the order of human nature, that is, the foundation and finality of all human action, it is therefore the final cause of political society, since the latter presupposes only a community of human beings united or consenting to an order or organization of their relations for the purpose of conservation of each one. This conclusion is logical in that nature, being in itself an order, cannot foresee a multitude of human beings who cohabit and whom it subjects to confirmation of their essence without an order that governs them. Thus society which in itself signifies an understanding, an agreement between individuals for the purpose of conservation, embodies precisely the order of natural means that governs them and that constitutes politics. However, the exact content of this order should be clarified by experience.

Thus on the basis of the substance of natural law or the natural state of affairs, the political animality of Man is first of all a natural nature, for, it does no longer require realization and is in force, whether or not the human being has reached this understanding, as opposed, as we shall see later, to its cultural nature, which, in turn, highlights this cognitive process of appropriation of the order of natural means. This natural nature can already be recognized in the reality of the family, which represents the primordial embryonic society.

\section{Family: The Primordial Embryonic Political Society}

Human security as the final cause of political society is still verified in the sense of the political animality of Man in the natural reality of the family. In fact, the family situates the beginning of man's political animality and, because of its original character, accounts for it as a natural nature. Before knowing this fully, let us begin by evoking certain apprehensions of the family.

According to Sébastien Bauer and Laurent Gerbier, in order to think about family, we must distinguish two elements that can alternatively found it: parentage and the community of residence. Parentage emphasizes the dual phenomenon of sexual completeness and inheritance (the family ensures permanence over time); the community emphasizes rather the original cell of together living, oriented towards work (Latin people include slaves and seasonal workers), or towards the existence of a non-biological affinity between individuals (the humanistic familia will then designate the circle of familiar: friends). ${ }^{23}$ Based on these distinctions, moral and political thought has made family a constant paradigm of its thinking: family thus represents the origin of the political community. ${ }^{24}$ Finally, family is an indissolubly ethical and legal concept: ${ }^{25}$ the natural (biological) model and the conventional model (affinity or social necessity) of living together are articulated within it. These models suggest that family is the place where the transition from nature to culture takes place ${ }^{26}$ or as a social machine for managing desires. ${ }^{27}$

23 BAUER Sébastien, GERBIER Laurent, "Famille”, in CNRS (Ed.), Grand Dictionnaire de la Philosophie, Larousse, Paris, 2003, pp. 1236-1237.

24 Ibid.

25 OURLIAC Paul, GAZZANIGA Jean-Louis, Histoire du droit privé français, II, 4, Albin Michel, Paris, 1985.

26 LEVI-STRAUSS Claude, Les structures élémentaires de la parenté, PUF, Paris, 1949.

27 DELEUZE Gilles, GUATTARI Felix, L’anti-CEdipe, Minuit, Paris, 1972. 
According to the first sense of parentage, family is presented as concomitant with the birth of Man. Every human being is born from a Man and a Woman and together they are essentially supposed to constitute a family. Family is therefore made up of at least three persons: the father, the mother and the child. Thus according to Aristotle, "First of all, there is necessity in the coming together of two beings who cannot anything without each other: I am referring to the union of the sexes for reproduction. And there is nothing arbitrary about this; for, in Man, as in other animals and plants, it is a natural desire to want to leave behind a being made in one's own image". 28 Thus naturally man and woman are made to be together. They are naturally endowed with dispositions that enable them to reproduce their species and in so doing they constitute family. Thus family is the most natural association, for it is not even necessary for Man to discover it through a n educational process. Man does not come to the conclusion, as a result of a process of experimentation, that he must belong to a family; the family is concomitant with his birth. "Thus, the natural association of every moment is family." 29

In order for it to be the embryonic political society for the purposes of our present analysis there must be an order. Indeed, if women and men are inclined to unite naturally and form a family with children, it is clear that the purpose of this association is the conservation of all its members. It is only in this way that all can confirm the order to which nature has essentially subjected them to. How could it be so without consent, without agreement and finally without order? It must therefore be assumed that whatever the nature of relations between the members of a family, they are not governed by disorder, whose consequence is self-destruction of members, what is not natural, but they are governed by an order whose purpose is their conservation, what is natural. Thus the family natural association confirms that it is, according to nature, an order. In this natural institution, which must be described as an embryonic political society, members are in fact pursuing their conservation of their nature, accounted by human security. And this is precisely the vocation of the larger forms of political society. For family, it is then said that Man's political animality is a natural nature to mean that the law of his nature and his life experience perfectly match.

Having made these clarifications, it is necessary to return to certain elements of the definition of family which seem debatable. The family is perceived as articulating the natural or biological models and the conventional model (affinity or social necessity) of living together, these models suggesting that family is the place where the transition from nature to culture takes place or as a social machine for managing desires. Starting from the fact that human nature is in itself a state of affairs or an order that does not need to be realized any longer but confirmed, it is clear that the order of means to this purpose is already a reality of nature. Consequently, this order of means is also no longer to be created but to be discovered. Under this understanding, everything that concerns the human being is part of a logic of conformation to his nature. Thus, whatever the biological or conventional dimension of family, it remains within the natural framework. It is therefore not a question of the passage from nature to culture, but of a permanent nature whose quintessence is discovered through the cultural process. 
On the basis of these considerations, human security as the order of human nature, is, therefore, the final cause of political society which begins with and in the family. At this level it should be pointed out that although it is real in itself and at the primordial level of family, the order of means that embodies political society in its broad dimension may be more or less known to all human beings who are naturally subject to cohabitation. And this has consequences for confirmation.

\section{B. SUBSTANCE OF UNDERSTANDING OF THE ONTOLOGICAL RELATION BETWEEN HUMAN SECURITY AND POLITICAL SOCIETY}

Human nature is also rational and this implies that it is called to understand the natural order of means for confirming the order of its nature both individually and in cohabitation with a multitude of fellow human beings. The necessity of nature's resources for the conservation of human beings has a great influence on the substance of human understanding of this order. Indeed, it must be postulated that the availability or deficiency of these resources for a multitude of individuals necessarily determines how the situation is managed. Thus, the natural order of means which presupposes the best mode of conservation for each individual of the multitude in such a situation can more (1) or less (2) be understood.

\section{The Understanding Of Human Security As The Final Cause Of Political Society}

The understanding of human security as the final cause of political society by human beings can be achieved in close or distant family relationships. According to Aristotle, "The primary association of many families, but made up for the purpose of relationships that are no longer daily, is the village, which might well be called a natural colony of family; for individuals who make up the village have, as other writers have put it, "sucked the milk of the family"; they are its children and "children of its children's". If the first states were subject to kings and if the great nations are still subject to kings today, it is because these states were made up by elements accustomed to royal authority, since in the family the oldest is a true king; and the family's colonies filially followed the example given to them. Homer was therefore able to say: "Each one of them governs his own wives and sons." At the beginning, in fact, all isolated families governed themselves in this way. Hence again the common opinion subjecting gods to a king; for all peoples once recognized or still recognize the royal authority and men have never failed to give their customs to gods, just as they represent them in their own image." 30

The fact of postulating the final political society, which is the state, from its family oriented village, implies the existence of an affective or family relationship between members of the state. Indeed, as we have seen, family members are inclined to a natural bond of solidarity, wherein affection is certainly the foundation. How can we think otherwise? Let us imagine that the bond between members of a family is hatred or simply indifference. In the hypothesis of hatred, the relationship between family members would certainly be one of hostility, the consequence of which would certainly be their selfdestruction. In the hypothesis of indifference between family members, the relationship would be 
individualistic, since each would be turned towards managing his or her own affairs, which would certainly be evidence of a lack of union, agreement and therefore disorder leading to the separation of family members. These hypotheses cannot therefore be proven by the fact that their results would lead to denying family in its natural essence. Knowing that family is a natural reality and that the individual is inclined to conserve himself for the sake of the permanence of his nature, it is necessary to postulate that an affective solidarity between members of family is part of this logic, because it works towards this purpose or this finality.

Thus, according to Aristotle's understanding, the finite political society that is the state is logically based on affective solidarity, because in fact it would constitute family on a somewhat larger scale. What is certain is that this affection would have its source in filiation that naturally unites the members of family. Viewed that way, we could believe that the understanding of the order of means that should conserve the essential state of human security for everyone is proven.

How can we therefore consider the issue of nature's resources? Indeed, in the hypothesis that these resources are available to all members of the group, one must ask oneself what would be the usefulness for a family group to organize itself. Individuals gather around a political society to solve or organize the management of a situation of general interest. There can only be politics if individuals find themselves confronted with a problem that needs to be solved by mutual agreement. Aristotle acknowledges this himself when he states that political society is established for the satisfaction of needs: "Association of several villages constitutes a complete state, reached, one can say, at this point of being absolutely self-sufficient, born first of all from the needs of life, and subsisting because it satisfies them all." 31 So, in a situation of sufficient resources for all families, there would be no additional need to organize because all would be sufficient. In this hypothesis and in the Aristotelian logic, political society could not be the object of a decree but of something natural, a simple sum of villages united by filiation. Even the title of king or any other denomination of chief would have no political value, that is, the authority responsible for ordering relations between members of the extended family. This title would then be rather honorary. But it should also be considered that if resources of nature are sufficient for all families and although they would maintain emotional ties, the need for reproduction should be considered, which would force the members of various families to look for partners outside their family or at least the nuclear one. This must be noted because it is a situation that would certainly require agreement between families and an authority responsible for managing disputes. This case implies an organisation between families that is much more demanding than the simple emotional solidarity unifying them. Thus a head would be responsible for ensuring order within this extended family. It is only in such a configuration, in the absence of a deficiency of nature's resources, that a group of villages would be a political society in a strict sense, since it would embody the order that should govern relations between the members, necessarily for the purpose of confirming human security as the order of their nature.

In the hypothesis of difficulties to enjoy resources of nature, due to their deficiency or the impossibility of their acquisition by a single family, families or villages should necessarily organize themselves. 
If resources are deficient for all, each one wishing to appropriate them for its own conservation, the management of this situation would be based on the choice between two alternatives: conflict or agreement. Being members of the same family, it should be borne in mind that the family link between them is likely to influence the option for an agreement. This order would be political in that it would consist in the manifestation of an organization for the general conservation interest of all members. In the hypothesis of difficulty in the acquisition of resources by a single family, all can agree to overcome the difficulty together. The resulting order would then govern a situation of general interest, which would certainly include guarantees that the agreement would be respected. Thus Aristotle thought that "Every state is obviously an association and every association is made up for the sole purpose of any good, since men, whoever they may be, never do anything but what seems good to them. Obviously all associations are concerned with a good of a certain kind, and the most important of all goods must be the object of the most important of associations, the one that contains all the others; and this one is precisely called State and political association". 32

All these developments allow us to know that the understanding of human security as the final cause of political society can be proven if it is derived from family relationships underpinned by emotional solidarity. Affection between members strongly influences and facilitates the understanding that the order of means confirming the law of human security is based on understanding or agreement between members when they face natural challenges. Even without having a proper declination of this order, we, at least, know that we are in the sense of a conformation to nature that cannot foresee cohabitation of a multitude of human beings and subject them to an imperative of conservation on the basis of disorder. If this understanding can be facilitated in Aristotle's hypothesis, demonstrating Man's political animality in the hypotheses of other scholars is not the case.

\section{The Possible Misunderstanding Of The Law Of Human Security As A Law Of Political Society}

The understanding of human security as a law of political society may not be understood by human beings under certain circumstances that need to be addressed. And the obvious consequence is the risk that human security may not be confirmed at the individual level. Although we have noted that family constitutes the embryonic political society, it is possible to envisage situations in which filiation between families or village members is, if not non-existent, so remote or distant or indirect as to become insignificant in the daily lives of individuals. It is opportune to note this situation in view of the configuration of present-day societies which, even if they were based on filiation, their current heterogeneous and composite nature raises the question of politics in a more objective way. Thus it is necessary to formulate hypotheses adapted to this situation in order to give a better account of man's political animality, but in the sense of a natural nature misunderstood by human beings.

Political society certainly began with family. Let us take the hypothesis of several families or several villages which, in the sense of Aristotle, would constitute society, but which would not be united by 
a parentage bond and which would be subject to the imperative of cohabitation and confronted with difficulties in acquiring resources of nature. In such a hypothesis, the different families or villages would have the choice between the two alternatives, which are conflict and agreement. Since the different protagonists are not united by a bond of parentage or identity that would automatically lead to managing the situation on an affective basis, it is doubtful that they would come to an agreement all the way. If they do have this idea, it would still be necessary to know what reasons would lead them to such a decision. At the very least, it must be assumed that they would realize the negative consequences of conflict or the unsuccessful consequences of individualism. All these postulates correspond well to the myths of the state of nature as developed by Thomas Hobbes ${ }^{33}$ and John Locke. $^{34}$

Thomas Hobbes asserted that to understand political society, it is first necessary to understand its members, that is, individuals. We must then understand the agreements that make up society and from these agreements we will understand the form and status of political society. The myth of the state of nature is then used to simply understand what human beings are. Self-preservation is the most fundamental desire and if there is no law or authority to influence our action regarding this desire, as viewed by Hobbes, no one has the power to dictate to other how to stay alive. According to Hobbes, the state of nature is a state of war. This conclusion stems from the consideration men have for one another. Indeed, men are naturally equal in body and mind, regardless of their abilities. Thus, no one can avail himself of his great strength or quick-wittedness of mind against others, for a man can overcome a stronger opponent either by using his wits or by joining with others who are similarly in danger to overcome the threat. ${ }^{35}$ Hobbes wrote again that men generally tend to covet power and fight to death for it. ${ }^{36}$ Thus in the state of nature, there is no way for anyone to be totally safe since every kind of force shows limits. Since all men are basically equal, there is no common power to watch over them. That is why a state of war would exist among them. Thus, according to Hobbes, distrust to each other characterizes the state of nature and since no one can trust anyone, everyone has to fear everyone. And it is this fear that grounds the state of war that renders man incapable of enjoying life and its properties. The state of war means "every man against every man. Where there is no common Power, there is no Law: where no Law, no Injustice. Force, and Fraud, are in war the two Cardinall vertues, ..., It is consequent also to the same condition, that there be no Propriety, no Dominion, no Mine and Thine distinct; but onely that to be every mans that he can get; and for so long, as he can keep it ..."37 Such a state lets few possibilities for cooperation : "there is no place for Industry ... no commodious Building ... no account of Time; no Arts; no Letters; no Society; and which

33 HOBBES Thomas, Léviathan, Traité de la matière, de la forme et du pouvoir de la république ecclésiastique et civile, 1651, traduit de l'anglais par FOLLIOT Philippe à partir de HOBBES Thomas of Malmesbury, Leviathan or the Matter, Forme and Power of A Commonwealth Ecclesiastical and civil, London, Printed for Andrew Crooke, 1651, Chicoutimi, Québec, janvier 2004.

34 LOCKE John, Traité du gouvernement civil, 1690, trad. française de MAZEL David, 1795 à partir de la 5 ème édition de Londres publiée en 1728, Chicoutimi, Québec, 2002.

35 HOBBES, op. cit. p. 107.

36 Ibid. p. 88.

37 Ibid. p. 110. 
is worst of all, continually fear, and danger of violent death; And the life of man, solitary, poor, nasty, brutish, and short." 38

Following Hobbes, Locke made a state of nature account. Locke asserted that it is unlikely to find traces of the state of nature because the traces only begin with civil societies which are political societies. However, Locke tried to show, from his point of view, what could be the most likely origin of civil society. In his Second Treatise on Civil Government, John Locke agrees with Hobbes that the state of nature is a state of perfect freedom and equality. But he meant the two terms differently. According to Hobbes, equality refers to the ability to gain power and satisfy one's desires, while freedom just means that everyone has the natural right to do whatever he or she thinks is necessary to secure self-preservation. Locke, on the other hand, supports a moral interpretation of each term. Equality means that no one has the right to have power over anyone. And while everyone has the right to self-preservation, Locke argues that there are limits to what can be done for this purpose, according to the law of nature. The law of nature prescribes that no one may subordinate another person or harm his life, health or property (except in self-defense), and furthermore that men must help one another when it does not cause them harm. Thus, according to Locke, the state of nature is the state of liberty and not of license, because it is governed by the law of nature. It appears, however, that there may be individuals in the state of nature who do not live according to the laws of nature, and in this case, too, the law of nature prescribes the extent of action in reaction against such criminals. In the state of nature men have the right to defend themselves and their property. However, it is possible that the reaction to the criminal act may be disproportionate because it is possible to react by murder to theft. The greatest objection to the state of nature according to Locke is therefore the possibility that natural freedom is abused both in the non-consensual interference in another individual sphere and in the reaction to it. ${ }^{39}$

Thus the myths of the state of nature developed by Hobbes and Locke confirm Man's natural tendency to conservation. However, the fundamental point of divergence is the way it is assumed.

Indeed, according to Hobbes, in the state of nature Man is a wolf to Man as they are all in search a natural egalitarian basis. To protect themselves, competition and rivalry therefore become their day to day way of life. Since men cannot trust one another to respect the natural law for each and for all, mistrust is the most widespread feeling. Thus in Hobbesian state of nature, the conservation of the being is done in short by means of violence. ${ }^{40}$ It is the war of all against all. According to Locke, men being naturally equal in freedom and naturally inclined to rationality, conservation of being is naturally done or is called to be done peacefully because any idea of subordination of one man by another is impossible or at least inadmissible. ${ }^{41}$

38 Ibid. pp. 108-109.

39 RUSSELL Bertrand, A History of Western Philosophy and its Connection with Political and Social Circumstances from the Earliest Times to the Present Day, Simon And Schuster, New York, 1945, p. 626.

40 HOBBES, op. cit. p. 106.

41 "The natural state of men, before they had formed societies, was a perpetual war, and not only that, but a war of all against all”; LOCKE, op. cit. p. 19. 
Finally, Hobbes and Locke agree in that human being is an individualistic being. ${ }^{42}$ But they disagree on the conception of this individualism. Hobbes conceives human individualism as referring to natural selfishness, whereas Locke understand it naturally altruistic. Now, Locke assume the state of nature favors permanent insecurity: which is the possibility of irrational human behavior contrary to their true nature and then the possibility to abusively interfere into the freedom of others. ${ }^{43}$ Locke believed man's rationally altruistic natural individualism in the state of nature, is the principle and man's irrationally selfish natural individualism is the exception. According to Hobbes, the rationally selfish natural individualism in the state of nature is the principle without exception. The solution to this exceptional and principle-based problem leads these authors to tackle differently the state of society. Thus since the problem was conceived differently, the solution in turn could only be different.

The myths of the state of nature are therefore hypotheses that correspond to the case of a group of individuals who naturally find themselves subject to the imperative of individual conservation without sustaining a link of filiation and on the basis of the resources of nature. The state of nature as characterized by the two authors would be a state of insecurity that naturally leads to the nonconservation of all, what emphasizes the importance attached to the solution of this problem, that is, the forthcoming political society. This one would be presented only as an agreement between individuals, having understood the consequences of conflict, of the licentious behavior or simply of the state of nature's ambient disorder.

Although this situation allows us to understand that the political animality of man, as a natural nature cannot be so understood, we must take this opportunity to evaluate hypotheses of the state of nature in the sense of the natural, or essential order of human security. It is quite clear that these states of nature are not traceable historical realities, but constructions which make it possible to grasp the foundation and the purpose of political society. If it is already necessary to recognize that security certainly constitutes the foundation and the finality of this one, one must still examine its nature. The myths of the state of nature focus on the behavior of people in their natural tendency for conservation. These myths therefore only deal with human security. However, these myths seem to contradict the political animality of Man, since he would only be a political animal outside of the state of nature. This is undoubtedly contradictory to Aristotle's postulates. In the understanding of the essential human order that is human security, it is a question of knowing that nature in itself is already an order which is no longer to be realized, since it is already real though is to be confirmed. In this logic, since nature has subjected to cohabitation a multitude of human beings and with a dependence on its resources, it is clear that it has foreseen an order of means under and by which their conservation is ensured. Although the human being may not understand this order in a state of nature - as developed by these myths - and therefore may not know his political animality as a natural nature outside of the family framework, this does not prevent this nature to be real, because

42 TRICAUD François, "Hobbes et Locke: convergences et divergences", in: XVII-XVIII, Bulletin de la société d'études angloaméricaines, des XVIIe et XVIIIe siècle, n. 25, 1987, p. 77, http://www.persee.fr/doc/xvii_0291-3798_1987_ num_25_1_1120(30.03.2021). 
it dictates a necessity of confirmation. Thus, although the relevance of the myths of the state of nature is proven, their value is surely limited if they do not somehow take all the relevant elements or logics of reality into consideration. Since Man is always part of nature, he is therefore a political animal and that is why we must agree with Aristotle that the State which is a form of political society is just as natural. But if it is no longer a natural nature with regard to the hypothesis that makes it possible to envisage political society without any bond of filiation, the best way to understand the myths of the state of nature of Hobbes and of Locke is the one according to which they inform on the incomprehension or the ignorance by the human being of the natural order of means intended to conserve himself according to the essential order of his nature that is human security. The various solutions of agreement, contractual or order to which they lead to are not sufficient to see in political society as belonging to Man's nature. In this case the State, according to the particular formulation consequential to each myth, is a creation or an artifice distinct from the nature, but they then appear as the beginning of an understanding or awareness of the natural order according to which all can confirm the essential order of their nature or preserve themselves only on the basis of a regulation or normalization of their relationships. This brings political society into the political animality of man, but as a cultural nature. In one level or another, human security is verified as the final cause of political society.

\section{THE POLITICAL ANIMALITY OF MAN: A CULTURAL NATURE}

In the first section, we undertook to verify human security as the final cause of political society by dwelling on the Man's political animality as a natural nature. By this concept we meant an adequacy of the essential human nature's order of human security with the understanding and the experience of the human being. By the concept of cultural nature in this context, we mean that the natural order of means for the conservation of human nature in it is essential state of human security in a context of cohabitation is not always known by the human being and so discovered as a result of experience. ${ }^{44}$ Culture generally refers to the body of knowledge acquired. Culture is often distinguished from nature apprehended as referring to the innate while it refers to the acquired. We will understand it here as the educational process of Man on the order of natural means which should enable him to confirm himself in coexistence with several fellows. While Man's political animality fully remains in the natural order as complementary to his family aspect, it is revealed or gradually clarified to him as a result of the consequences of his initiatives for the purpose of confirming his natural essential state of security. Thus it will be clear that the Man's understanding and experience are not always in compliance or become so step by step or by experience. Man's political animality as a cultural nature will mean a nature which is known through education or quite simply which is discovered through experience. The cultural nature of human political animality to account for human security as the final cause of political society will be verified in the community management of conservation (A) which unveils a human undertaking of conformation with natural order (B).

44 CHARRAK André, "Culture”, Grand Dictionnaire de la Philosophie, op. cit. p. 691. 


\section{A. THE COMMUNITY MANAGEMENT OF CONSERVATION}

Since the community management of conservation is evidence of the cultural nature of Man's political animality, it is implemented when individuals understand that consent or agreement is preferable to conflict and that collectivism is preferable to individualism. Thus, in the logic of confirmation of the essential order of human security, political society is known as necessary (1) and the knowledge of the order of natural means which can lead to this finality follows. Even if its form is not circumstantially accomplished, Man's rationality at work allows him to get closer to it (2).

\section{Necessity Of An Agreement}

The necessity of an agreement is the understanding to which a group of individuals subject to cohabitation by nature and who find themselves around something of common interest necessary for conservation. So agreement is the determinant of political society. Let's try to understand its logic.

Agreement is a manifestation of the will to behave in a certain way. It is a manifestation of freedom that has to be understood as one of the human natural attributes. Freedom therefore comes under natural law and is rightly at the centre of the myths of the state of nature. Given that each human is a liberty, it is therefore unnatural for anyone to be subject to others because that would imply opposing to him an intolerable lack of self-determination. Since freedom is part of the natural order, it cannot be harmful because it is only in this order that it participates in human security. Thus, it must be differentiated from license. By license we mean the possibility for a person to act in all directions, according to his whims, without his actions being subject to control. In fact, licentious behavior involves disorder or chaos, since its actor can behave without restrictions, so he is able to harm others or himself. However, causing harm to others or to himself possibly implies a painful consequence for the actor because it is probable that, because of the pain abusively caused to others, the latter takes revenge, or because of the pain he inflicts on himself, he necessarily feels pain or even faces death. Liberty, on the contrary, implies an order of behavior which is measured, thought, rational, reasonable in the sense that the actor behaves with a view to the positive consequences of his action for himself. Free behavior can therefore never, in itself, have harmful consequences for who sustains it, because he would respect, as the case may be, himself and/or others. Licentious behavior is therefore in itself evidence of an absence of order.

The myths of state of nature emphasize that Man would sustain a false understanding of freedom when he would believe that he is allowed everything in the necessity of his conservation. But instead of benefiting from that, he rather loses and consequently he gradually comes to be aware that freedom means to behave in a way that does not harm himself or others. This way consists in agreeing with his fellows on a union aiming the conservation of each one. This agreement is understood precisely in terms of "social contract". The formulation of this one corresponds to the concept of liberty in the state of nature.

According to Hobbes, the state of society consists in this political form where all individuals concede their full powers in the hands of a single person or an assembly, ensuring security for all. Now with 
the whole force and monopoly of its exercise, this individual or this assembly has all guarantees to be feared and to establish order and therefore a climate where everyone can pursue his own conservation safely. ${ }^{45}$ According to Locke, however, the individual, being naturally free, the social configuration he envisions is one that confirms this nature of Man. Thus, transition to society involves a contract among all individuals to create this entity which will ensure the security of everyone in his natural freedom to preserve himself. And the authority in charge of the power conferred by the social contract is responsible for its government before all individuals who can thus revoke him because they would have kept this freedom to do so. ${ }^{46}$ This is what fundamentally makes the difference with Hobbes because individuals, by fully conceding their freedoms to one, it is clear that they do no longer have the possibility of removing him unless he becomes logically irresponsible towards his fellow counterparts. He is accountable only to himself. ${ }^{47}$ This way of conceiving political society would ultimately suggest that freedom is the most harmful element for all parties and therefore the solution is only found in renunciation. The conservation of the being thus require, according to Hobbes, renouncing to freedom that founds the State. Now according to Locke freedom is the most characteristic good of Man and it is only because he can be threatened in an irrational way in the logic of confirmation of his being in the state of nature that political society is agreed. The conservation of the being cannot then be possible through the renunciation of freedom but through its conservation because it remains the only bulwark against the governors who would decide not to respect the social contract.

It is also relevant to mention that the social contract as understood by Rousseau is very edifying on how to organize relationships between naturally free individuals while confirming this natural attribute. $^{48}$

45 RUSSELL, op. cit. p. 555.

46 RUSSELL B., op. cit. pp. 629-633.

47 HOBBES, op. cit., p. 132.

48 Before elaborating it, he begins by assuming that "men to have reached the point at which the obstacles in the way of their preservation in the state of nature show their power of resistance to be greater than the resources at the disposal of each individual for his maintenance in that state. That primitive condition can then subsist no longer; and the human race would perish unless it changed its manner of existence" Then he continues by saying "but, as men cannot engender new forces, but only unite and direct existing ones, they have no other means of preserving themselves than the formation, by aggregation, of a sum of forces great enough to overcome the resistance. These they have to bring into play by means of a single motive power, and cause to act in concert. This sum of forces can arise only where several persons come together: but, as the force and liberty of each man are the chief instruments of his self-preservation, how can he pledge them without harming his own interests, and neglecting the care he owes to himself? This difficulty, in its bearing on my present subject, may be stated in the following terms: "The problem is to find a form of association which will defend and protect with the whole common force the person and goods of each associate, and in which each, while uniting himself with all, may still obey himself alone, and remain as free as before." This is the fundamental problem of which the Social Contract provides the solution. The clauses of this contract are so determined by the nature of the act that the slightest modification would make them vain and ineffective; so that, although they have perhaps never been formally set forth, they are everywhere the same and everywhere tacitly admitted and recognised, until, on the violation of the social compact, each regains his original rights and resumes his natural liberty, while losing the conventional liberty in favour of which he renounced it. These clauses, properly understood, may be reduced to one the total alienation of each associate, together with all his rights, to the whole community; for, in the first place, as each gives himself absolutely, the conditions are the same for all; and, this being so, no one has any interest in making them burdensome to others. Moreover, the alienation being without reserve, the union is as perfect as it can be, and no associate has anything more to demand: for, if the individuals retained certain rights, as there would be no common superior to decide between them and the public, each, being on one point his own judge, would ask to be so on all; the state 
Although our three authors conceive the form of agreement differently, representing the social contract or political society, they all recognize nevertheless that it is a necessity. It is only in this way that a set of individuals who must preserve themselves according to the essential order of their nature can achieve this finality. However, in our view, this necessity is related to the natural order which is already real and which has only to be discovered and known by Man. Thus, the best formulation of political society can only be discovered or known as a result of its consequences for human security. So Man's political animality is a cultural nature. "Hence this obvious conclusion, that State is a fact of nature, that naturally Man is a sociable being" ${ }^{9}$. Aristotle further justifies this in these terms: "If man is infinitely more sociable than bees and all the other animals which live in a herd, it is obviously, as I have often said, that nature does nothing in vain. However, it gives voice to man exclusively. Voice can express joy and pain; also it is not lacking in other animals, because their organization goes so far as to feel these two affections and to communicate them. But speech is made to express good and evil, and therefore also the just and the unjust; and Man has this special thing, among all animals, that he alone sees good and evil, the just and the unjust, and all feelings of the same order, which by being associated constitute precisely family and State" ${ }^{50}$ It is then impossible for Man to conserve himself outside the natural order of means that political society embodies because in himself alone he can exercise the rational component of his nature to discover it through exchange with other citizens on the just and the unjust. That said, resources of nature are very much involved in this exercise of human rationality.

\section{Resources As A Condition Exercise Of Human Rationality}

It is necessary to recall the immense participation of resources in the exercise of the rational component of human nature in the discovery of the natural order of means necessary for the confirmation of the human essential order of human security, in coexistence with a multitude of other human beings. Indeed, these resources as we have seen, are useful to conserving the physical nature of Man and we postulate that they condition the cultural nature of man's political animality.

of nature would thus continue, and the association would necessarily become inoperative or tyrannical. Finally, each man, in giving himself to all, gives himself to nobody; and as there is no associate over whom he does not acquire the same right as he yields others over himself, he gains an equivalent for everything he loses, and an increase of force for the preservation of what he has. If then we discard from the social compact what is not of its essence, we shall find that it reduces itself to the following terms: "Each of us puts his person and all his power in common under the supreme direction of the general will, and, in our corporate capacity, we receive each member as an indivisible part of the whole." At once, in place of the individual personality of each contracting party, this act of association creates a moral and collective body, composed of as many members as the assembly contains votes, and receiving from this act its unity, its common identity, its life and its will. This public person, so formed by the union of all other persons formerly took the name of city, and now takes that of Republic or body politic; it is called by its members State when passive. Sovereign when active, and Power when compared with others like itself. Those who are associated in it take collectively the name of people, and severally are called citizens, as sharing in the sovereign power, and subjects, as being under the laws of the State. But these terms are often confused and taken one for another: it is enough to know how to distinguish them when they are being used with precision" ROUSSEAU Jean-Jacques, Du contrat social ou Principes du droit politique, 1762, Document produit en version numérique par TREMBLAY Jean-Marie, Les classiques des sciences sociales, Paris, 1963, p. 17.

SAINT-HILAIRE, op. cit. Book I, I. 8.

Ibid. Book I, I. 9. 
Reading the myths of the state of nature developed by Hobbes and Locke, one must note the central place that takes resources of nature in the individual conservation undertaking, although they do not say it clearly. However if Hobbes does not make enough mention of goods necessary for conservation as noticed from the logic of his developments, Locke on his part makes clear mention of them as invaluable for conservation.

According to Hobbes "From this equality of ability arises equality of hope in the attaining of our ends. And therefore if any two men desire the same thing, which nevertheless they cannot both enjoy, they become enemies; and in the way to their end (which is principally their own conservation, and sometimes their delectation only) endeavour to destroy or subdue one another. And from hence it comes to pass that where an invader has no more to fear than another man's single power, if one plant, sow, build, or possess a convenient seat, others may probably be expected to come prepared with forces united to dispossess and deprive him, not only of the fruit of his labour, but also of his life or liberty. And the invader again is in the like danger of another." ${ }^{51}$ For his part, Locke extensively discusses ownership of things whose origin he immediately clarifies: "Whether we consider natural reason, which tells us that men, being once born, have a right to their preservation, and consequently to meat and drink and such other things as Nature affords for their subsistence (...) The earth and all that is therein is given to men for the support and comfort of their being. And though all the fruits it naturally produces, and beasts it feeds, belong to mankind in common, as they are produced by the spontaneous hand of Nature, and nobody has originally a private dominion exclusive of the rest of mankind in any of them, as they are thus in their natural state, yet being given for the use of men, there must of necessity be a means to appropriate them some way or other before they can be of any use, or at all beneficial, to any particular men. The fruit or venison which nourishes the wild Indian, who knows no enclosure, and is still a tenant in common, must be his, and so his i.e., a part of him, that another can no longer have any right to it before it can do him any good for the support of his life." 52

Hobbes and Locke make the conservation of man the primary objective of human nature and resources or assets are the necessary elements for this purpose. With regard to the state of Hobbesian nature, it is not very illogical to assume that it is these goods for conservation which are the real stake that leads to the state of war, each seeking to secure an advantage. If these goods are enough or sufficient for all, what could well be the source of conflict if all are inclined to conserve themselves? That importance of goods in the Hobbesian myth justifies the fact that "In such condition there is no place for industry, because the fruit thereof is uncertain: and consequently no culture of the earth; no navigation, nor use of the commodities that may be imported by sea; no commodious building; no instruments of moving and removing such things as require much force ..." ${ }^{33}$ As means of conservation, goods would therefore be so coveted that in the end their production becomes almost impossible, since the owner is not certain to enjoy them. As far as Lockean state of nature is concerned, the equitable use of natural resources for the just need of conservation and the peaceful personal enjoyment of property are not always guaranteed, although human beings are rational. "If man in the state of Nature be so free as has been

51 HOBBES, op. cit. Première partie: De L'Homme; Chapitres I à XVI, p. 107.

52 LOCKE, op. cit. pp. 34-35.

53 HOBBES, op. cit. p. 108. 
said, if he be absolute lord of his own person and possessions, equal to the greatest and subject to nobody, why will he part with his freedom, this empire, and subject himself to the dominion and control of any other power? To which it is obvious to answer, that though in the state of Nature he hath such a right, yet the enjoyment of it is very uncertain and constantly exposed to the invasion of others; for all being kings as much as he, every man his equal, and the greater part no strict observers of equity and justice, the enjoyment of the property he has in this state is very unsafe, very insecure. This makes him willing to quit this condition which, however free, is full of fears and continual dangers; and it is not without reason that he seeks out and is willing to join in society with others who are already united, or have a mind to unite for the mutual preservation of their lives, liberties and estates, which I call by the general name-property." ${ }^{4}$

If goods for conservation take in the state of nature, a less obvious place in the theory of Hobbes and more evident in the theory of Locke, the fate which they receive inside the model of political society proposed in solution to the state of nature is much less problematic in Hobbes than in Locke. Indeed, Hobbes asserts that "The nutrition of a Commonwealth consists in the plenty and distribution of materials conducing to life ... For the matter of this nutriment consisting in animals, vegetables, and minerals, God hath freely laid them before us, in or near to the face of the earth, so as there needs no more but the labour and industry of receiving them ... The distribution of the materials of this nourishment is the constitution of mine, and thine, and his; that is to say, in one word, propriety; and belonged in all kinds of Commonwealth to the sovereign power. For where there is no Commonwealth, there is, as hath been already shown, a perpetual war of every man against his neighbour; and therefore everything is his that gets it and keeps it by force; which is neither propriety nor community, but uncertainty ... Seeing therefore the introduction of propriety is an effect of Commonwealth, which can do nothing but by the person that represents it, it is the act only of the sovereign; and consists in the laws, which none can make that have not the sovereign power. And this they well knew of old, who called that Nomos (that is to say, distribution), which we call law; and defined justice by distributing to every man his own. In this distribution, the first law is for division of the land itself: wherein the sovereign assigns to every man a portion, according as he, and not according as any subject, or any number of them, shall judge agreeable to equity and the common good." 55

Thus, it is in the political society that Hobbes comes to clearly recognize the inescapable nature of goods in the conservation of individuals and fix the issue of their availability as depending on the discretion of the sovereign. Although this solution is questionable in view of its implications for the confirmation of the law of human security, it is already important to recognize that this issue is crucial to this end.

Locke, for his part, proposes a model of political society which essentially deals with protecting the property of individuals whose enjoyment is threatened in the state of nature: "The great and chief end, therefore, of men uniting into commonwealths, and putting themselves under government,

54 LOCKE, op. cit. pp.85-86.

55 HOBBES, op. cit. pp. 72-74. 
is the preservation of their property; to which in the state of Nature there are many things wanting"56. Locke made of the protection of property a major goal of political society to such an extent that he anticipated and fix the hypothesis of any arbitrary interference of the sovereign in the enjoyment of property, no doubt in reaction to Hobbes. He sees this situation as unacceptable. However, it should rather be noted, in relation to the inescapability of goods for the conservation of individuals, a set of elements which can be considered as missing in this theory.

Indeed, the question of availability of goods necessary for conservation in political society does not really come up in Locke's political solution. In the state of nature, he deals with the appropriation of goods from nature. Not only should the rationality of principle of human beings lead them to an equitable use of the nature resources and to the respect of the appropriation of each one. Because it is possible for some to appropriate these resources more than what they need for their conservation, thereby harming others, that there is a possibility of unjust or abusive interference in the property of everyone and that is why an agreement is necessary between all individuals, for the purpose of better protection. This situation would either imply that everyone consents to political society by already owning a property which they would continue to enjoy in that frame, or that some do not own anything and nevertheless decide to consent to a political society, or that some have been dispossessed in the state of nature and could not have recovered their rights because the infringer was stronger and would nevertheless consent to political society, or that some having unjustly appropriated more than what was necessary for their own conservation and would consent to an agreement with others under such a title of property. In all these different hypotheses, consent to a political society would start on unequal and surely unjust basis, because it is possible either that it protects those who have behaved badly in the state of nature, or that it offers no alternative of property acquisition, for those who did not appropriate anything in the state of nature, of goods necessary for their conservation in the political society whose purpose is to allow the enjoyment of property in safety and in rest. Consequently, one would have to think either that such a political society would have little chance of surviving, since the non-owners of goods should find some to conserve if the political society does not provide them with anything. It is then possible that in the political society, they adopt behaviors of the state of nature, or that such an agreement of political society is impossible. Now, how would an individual who rationally used the goods of nature in an equitable way by recognizing the rights of others on the same property without appropriating it beyond the simple requirements of conservation consent to transfer his freedom to a society which would not provide him with the goods necessary for its conservation when irrational people have appropriated everything in the state of nature? Political society would then be contradictory to natural rationalism.

From the explanations above, the point that is raised is that political societies should regulate the availability of goods for the benefits of all given that nature has already gifted its goods to human beings for proper conservation. It is only based on these ones that the cultural nature of man's political animality is confirmed because he gradually discovers that he is, due to the unity of nature, in an order that includes him with all men and the whole nature, for, according to Hobbes, "This matter, commonly called commodities, is 
partly native and partly foreign: native, that which is to be had within the territory of the Commonwealth; foreign, that which is imported from without. And because there is no territory under the dominion of one Commonwealth, except it be of very vast extent, that produceth all things needful for the maintenance and motion of the whole body; and few that produce not something more than necessary; the superfluous commodities to be had within become no more superfluous, but supply these wants at home, by importation of that which may be had abroad, either by exchange, or by just war, or by labour: for a man's labour also is a commodity exchangeable for benefit, as well as any other thing: and there have been Commonwealths that, having no more territory than hath served them for habitation, have nevertheless not only maintained, but also increased their power, partly by the labour of trading from one place to another, and partly by selling the manufactures, whereof the materials were brought in from other places." 57

Though insisting on property, Locke also recognizes that "God, who has given the world to men in common, hath also given them reason to make use of it to the best advantage of life and convenience. The earth and all that is therein is given to men for the support and comfort of their being." 58

These developments lead us to the conclusion that what both authors have called "state of nature" actually refers to a set of irrational behaviors that human beings would adopt in their natural tendency for conservation. Now seeking only to ultimately conserve their nature, under equally natural conditions (multitude of similar human beings, resources of nature) how would the state of nature in itself be a problem to itself? This contradiction is impossible for nature because it is already an order, but it is attributable to man who has not yet understood the order of natural means provided so as to confirm himself under the conditions that this nature has subjected him to; which also proves some of the irrational behaviors that can persist within the agreed political society. Since Man is called upon to preserve goods, these drive human rationality in search of this order of natural means. Once again, we understand that human security is the foundation and the end of political society. And this is further verified through the social experience.

\section{B. The Social Experience, A Progressive Undertaking Of Conformation Of Man To His Nature}

The cultural nature of Man's political animality is accounted through the historical process of experimentation through which Man progressively discovers the order of natural means that confirms human security accounting of the order of his nature, within a multitude, using the resources of nature. So he is constantly looking for the best configuration of political society (1), until the order of means conforms to the order of ends (2).

\section{The Continuous Search For The Best Formulation Of Political Society}

After learning that conflict is unnatural through its effect of non-conservation, men come to realize that the consent and the agreement for a normalization of their relationships or what we call

57 HOBBES, op. cit. p. 73.

58 LOCKE, op. cit. p. 35. 
"political society" is pro nature because it allows this confirmation. If this is a good starting point, it is not generally sufficient for the discovery of the order of natural means by which the law of human security is confirmed. Thus men are involved in a perpetual search for the best formulation of political society which can allow them to conserve well. How does his work in order to account for the fact that human security is the final cause of political society?

Starting from the fact that a law of nature is a state of affairs, a state of things, a state of functioning, a reality, then it does not need to be created or realized, since it is already real. For human nature, this reality is reduced to an intrinsic dispositional state which is "security". Security or state of wellbeing therefore accounts for the natural human order so that it is not only a question of being a human being, but necessarily of being in security. Thus, this state, due to the rational animate human nature has the vocation to confirm itself, that is to say, to be as it is permanently. This is what is called conservation because, succeeding in this natural tendency, permanence is ensured.

Since nature has prepared or subjected man to confirm the order of his nature with a multitude of fellows also constrained to the same tendency and on the basis of resources which it contains, human security logically becomes the order of relationships that they can sustain between them. If licentious behavior or war or chaos or disorder results in the destruction and not the preservation of any of them, it is therefore unnatural and cannot in reality be considered as part of the order of means which confirms the natural law, which rather includes liberty, consent, agreement, organization embodied or signified in political society. Human security is therefore the final cause of political society, in that it constitutes its foundation and its finality.

Human security being the final cause for a group of individuals subjected to the same condition by nature, it is obvious that political society is part of the order of means that this nature necessarily foresee and whose exact formulation they are called to discover progressively. The Social experience to which we refer in this context is the process by which Man, for the purposes of its conservation, formulates organizational initiatives and face the resulting consequences. Reason then commands him to be aware of the order of natural means which is unveiled through initiatives resulting to positive consequences on conservation and which is knows not including those leading to negative consequences. Initiatives with positive consequences should then be capitalized and those with negative consequences should be either rejected or improved.

It is still necessary to ask ourselves what criterion is supposed to inform that a certain organization is a component of the order of natural means necessary to confirm the natural human order of human security.

Political society is made up in theory of all the individuals who have consented to be part of it. It is essentially the product or the sum of the agreements of individuals who constituted themselves so for the purposes of their conservation. They therefore all expect the same consequence: security. It is therefore clear that no political society which does not succeed, on the basis of its form, in meeting the natural conservation need of all the individuals who make it up would be failing. It is not even a question of confining oneself to the satisfaction of the majority because it is by individual agreement 
that individuals recognize themselves as members of a political society and therefore, if some of them do not obtain satisfaction as the expected reason for which they have given their agreement, it is clear that society is failing. Satisfaction of human security is a collective affair because it concerns all individuals in the same way. It is because each individual human security is the finality that collective human security has meaning. And it is in the expectation of everyone's security that political society exists. If it does not succeed, then it would present itself as not having fulfilled its objective. This is the meaning of the contractualist philosophy. All should be considered as equal contracting partners on a natural state to be conserved. If only one is not, there is a failure of the political society's formulation.

What could we expect from the lack of conservation of some? The displeasure of some individuals due to a lack of conservation would be an obvious consequence and one must think that they would have the choice between two alternatives: either to resign in front of the majority, or to defend their rights to be satisfied like everyone else. Resignation in such a situation would appear to be unnatural because it would result in accepting an insecurity which is naturally unacceptable. Only the defense of the right to conservation would be natural. It is therefore clear that individuals would hold the political society accountable and if necessary they would question the usefulness of continuing to respect their agreement. They may then seek to satisfy themselves outside of the order that political society constitutes. If the latter, in its current state of configuration, aims to embody order within a territory, it is therefore exclusive of any other order within its sphere of sovereignty. Thus, dissatisfied individuals should either continue to obey the order they would have consented without however receiving the conservation expected result, or leave. However, they can only settle in another place if that one is either without a master or not subject to an agreement under a political society. But if that is the case, they should be welcomed and authorized to stay by the members of such a society, therefore allowing them to conserve themselves with them even though they would not have from origin consented to that society. This would be a benevolence with a precarious status because it is possible that this benevolence is not or no longer granted and that dissatisfied individuals in their society are pushed to leave. So in situations where benevolence is refused and there are no more territories without masters, it is clear that the only option that would remain for individuals whose conservation is not satisfied in their societies is to return or simply stay and defend their rights to be satisfied like all other contracting member.

So a question is important: Is the situation of these disadvantaged individuals just a matter for themselves or their situation is a matter for all individual members of the political society?

Political society is, in an essentialist point of view, the sum of individual agreements, it represents an inter-individual agreement for a precise purpose which is the conservation of each. Because it is a matter of conservation of each individual that conservation of all matters. Political society therefore has an obligation of result because of its foundation and its finality: the law of security of each individual human nature that makes it up. It is therefore clear that if this order does not lead to confirmation of this natural intrinsic state, even of one, it is flawed in its formulation and must be reviewed. The satisfaction of the majority is therefore not the criterion of the viability of a political order, because that way, it testifies to its failure, in its current formulation, for it has not yet 
succeeded in reaching the level it can satisfy the agreement's expected counterpart of each member and therefore of all. The dissatisfied members must therefore draw other members' attention on this failure and require that the current formulation of the political society agreement be reviewed in the hope that each one can effectively see the counterpart of his consent satisfied. If the other consenters refuse due to their satisfaction in the present state of order and to the detriment of some, it is clear that they would enjoy the implementation of the unfair agreement. They would therefore forget that the political society on the basis of which they are satisfied is the sum of interindividual agreements and therefore that this in fact is a meta-synallagmatic contract since each individual would have consented to each other for his own conservation and the conservation of each other. If only one then fails to be satisfied, each of the contracting parties is defaulting towards him. Then it must be concluded that it is everyone's problem if only one of them is not satisfied in its conservation. And since it is the matter of each one, so it is the matter of all. For those who would have been satisfied would have benefited from the execution by each of the members of its obligation towards him including by the dissatisfied one, without this one in return benefiting from the same counterpart of the execution of obligation of and by every other member. Thus in a political society, all are responsible for the conservation of all, which means that each member is responsible for the conservation of each member. The dissatisfaction of one means that each member has not fulfilled his obligation. Could each of them do it? If everyone was satisfied with the performance of the dissatisfied member's obligation, this means that everyone could also fulfill their obligation to him. Thus it appears that it is each of them who failed. But since it is not a question of the political society or organization in itself but that of its current formulation which result in negative consequences for some, it is clear that it must be revised. It is this current formulation or the form that the agreement is currently taking which accounts for the failure of each member. Therefore it is necessary to change that formulation or that form in the hope that by the new one or in the correction of the old one, each other member be no longer considered to be defaulting towards the dissatisfied one.

In the hypothesis that the current form of the failing organization is not reviewed by all, each of the beneficiaries being content to rejoice, they would take pleasure in benefiting from the execution of the dissatisfied member's obligation without doing the same to him by executing his own obligation. It would be a flagrant injustice and the dissatisfied member can decide to withdraw his agreement which binds him to others and take care of his own conservation. If he recalls the foundation of political society and recognizes that the licentious behavior for the purpose of confirmation leads to negative consequences, he would have no other alternatives than withdrawing his agreement from such an organization. So this withdrawal of agreement would imply that he is no longer linked to anyone and that he vows to his own conservation through the means at his disposal. To this end, if the dissatisfied member behaves as a rational being by not to using violence to acquire the means necessary to his conservation, he would withdraw also his properties from the framework of the agreement, in case he saved any, in the Lockean hypothesis of contractualism, to deal only with his own situation. But if he did not save anything, in both the Hobbesian and Lockean hypotheses, then even the withdrawal of his agreement would undoubtedly harm him, because this withdrawal would not imply an alternative for his conservation. Thus withdrawing or not, his agreement will 
be worth the same thing because none of the alternatives would ipso facto assures him the means of conservation. But withdrawing his agreement would be more advantageous in that it would mean the return to an ultimate alternative of conservation: the licentious behavior. If he decides not to use it, he condemns himself to insecurity which would lead him to extinction. But as we have seen, insecurity, extinction being unnatural, the licentious behavior involving the use of all means in his possession, including force, cunning means, becomes a necessity for him. The question that arises in this hypothesis relates to the legitimacy of such a behavior.

It must be assumed that such a behavior would be an unwanted consequence by the dissatisfied member. All he is looking for objectively is his conservation in the same way as the others. But each of them not having fulfilled their obligation towards him, whereas he would have done it for each of them especially when they take delight in such an unfortunate situation, it must be thought that the licentious behavior in reaction to this unjust attitude, although it is a behavior of the state of nature in the sense of Hobbes and Locke, would in fact be reinstated by each member of the political society when he would have defaulted in his obligation towards the conservation of the dissatisfied member while each of them would have benefited from him. Since society is less an abstract entity than a sum of individuals acting in concert, non-compliance with the inter-individual agreement that it constitutes is in itself an indicator of a return to the state of nature in the sense of both authors. Thus the complacency in this state by each of the satisfied members without wanting to revise or correct it in a sense where it brings positive consequences for each and therefore for all, that would be the sign of a licentious behavior to the detriment of the dissatisfied member whose own would be but a reaction. Such an attitude is necessary so that each of the satisfied members be aware of the consequences of their complacency. By the licentious behavior of the dissatisfied member, it is thus possible that the property of each member of the political society be no longer guaranteed, for, the dissatisfied member not having means of preservation, he would target the means of the others. In this hypothesis everything is possible, because he uses force against any obstacle that would represent owners. In another hypothesis where the satisfied members in synergy on the basis of their satisfaction with the current form of the agreement would decide to eliminate the threat that would represent the dissatisfied member, in order to live peacefully within the framework of the agreement, their strength may be greater and they may reach their goal. But the question that would arise is whether the disappearance of the dissatisfied member would guarantee that no other member currently satisfied finds himself in the position of the dissatisfied one in the future. And if this is the case, would other members not react in the same way that they would have reacted towards the first dissatisfied member? So what would be left of the agreement that represent the political society? If the problems of such a society happen to disappear with the first dissatisfied member without any other member facing the same situation in the future, then this would be the ideal for each of the current satisfied members. But what happens to the first dissatisfied member is the indicator that this could have happened to everyone else on the basis of origin equality between the contracting parties. And therefore it is wrong that they would not recognize themselves in the person of the dissatisfied party, considering in addition that it is from them that the failure of the system would arise by not fulfilling their part of obligation towards him. It is therefore in a delusion that each member of the 
political agreement would find himself, if he does not come to recognize the state of nature he would have restored and within which he would think he would forever ensure security for himself. Since the state of nature according to the authors is not a guarantee of security, it would be possible that in the future everyone find himself in the position of the first dissatisfied party and experience the same fate as him. In the long run, how far would such a behavior lead? Inevitably the disappearance of all and that would ultimately entail that to nobody achieve the permanence demanded by the law of human nature. Such a conclusion would be truly extreme in that if the ultimate consequence of the loss of all is not envisaged in the treatment of the case of the dissatisfied member, it is possible that other members will become aware of it as other dissatisfied members would disappear and put themselves in the place of each of these ones, which would mean that they would see themselves as a satisfied today and a disappeared tomorrow. Then they would come to understand that the problem is not in the dissatisfied member but in the form of the organization. They will be educated that the current form of the organization is not the one that results in the conservation and therefore the confirmation of the natural law of human security for all because it rather gradually leads to the insecurity for everyone. They would therefore decide to focus on other forms the organization in a way that capitalizes on the causes and consequences of first errors and which aims to correct them. Thus this would testify that they would not yet have understood that when political society fails to satisfy the confirmation of the law of human security for one, all are in danger of this fact and that the result is not in the elimination of the dissatisfied member who could have been anybody, but in the revision of the form of the organization or formulation which remains the vector of the licentious behavior they would have been part of. But in fact, the licentious behavior is unnatural since it is the opposite of freedom, which involves behaving in a way that is not harmful to oneself and to others. Since it is possible that a licentious behavior be surreptitious due to the formulation of the agreement, the latter must therefore be considered as not corresponding to the natural order of means confirming the natural law of human security.

At this conclusion, members of the political society would testify that they are involved in a logic of discovery of the order of natural means that better confirm the essential order of their nature. By making use of their reason, they would be aware of the cultural nature of their political animality. What the authors have therefore called the state of nature still only refers to the licentious and irrational behavior that is likely to surreptitiously interfere within political society. This is verified in that this state, in the sense of Hobbes and Locke, was never a historical reality but rather took or takes in fact the form of a disorder alongside the state of real nature which is the real and constant natural order. Its force is known as well in the small substance that it can be the object in the family framework (nuclear or large) such as developed by Aristotle accounting for the natural nature of the Man's political animality, or in the higher substance that it can be the object or is called to be the object within the framework of the social experience accounting for the cultural nature of the Man's political animality in the sense of Hobbes and Locke. He would not stop until he is fully educated on the whole substance of the real order of natural means through which he confirms himself, in cohabitation with other men on the basis of the resources of this nature. 


\section{The End Of Experience: the Discovery of Tthe Order of Natural Means of Confirmation of the Essential Order of Human Security}

The cultural nature of Man's political animality is noticed through the historical experiential process of education for the discovery of the order of natural means aimed at confirming the human natural order of human security in a natural context of cohabitation with fellow human beings and depending on the resources of nature. Nature, being an order in itself, is therefore a process of conformation to it. We have seen that human security, as the final cause of political society is a natural nature and thus education through history or experience leads to a conformation of the cultural nature to the natural nature, that is to say the situation in which the natural order and human experience are in phase. This situation is characterized by the understanding of the harmony within the natural order embodied by human security in its finalized and finalitarian components. In this framework it is about the discovery of the best for or formulation of the social order by which each human being who consents to it permanently conserves himself. Such a situation would be the end of the social experience, because it implies that the educational process would be completed when men would discover the right and sustainable formula. Since they are involved in the historical process of experimentation to discover the order of natural means, it cannot be extended when it is grasped. Thus the historical process of experimentation would lead to a state of perpetual peace.

The cultural nature of human political animality is therefore bound to continue until it comes to the discovery of the political order naturally provided for the conservation of each of its members. A question deserves to be asked in this context: is the achievement of such a result a certainty in the future?

Security being the intrinsic dispositional state of human nature, and since it is thus essential, it is a real state. Being the foundation and finality of all human action for the purposes of conservation or permanence, it constitutes the order of human nature. In this logic, its permanent confirmation in what it is, is possible only in the order of means already foreseen by nature which has subjected men to cohabit and to depend on its resources. Since this order exists and is to be discovered, it is therefore knowable. So it should be thought that this knowledge is a reality in the world of men. In any case, it is a matter of knowing that as long as man has not come to know this order, he would find himself in a situation which is not very advantageous for its conservation and therefore that the process of experimentation is called to go on. One author thought that "History has been called, not without reason, an eternal restart. The accidental varies, the content (essence) - the substance, would say philosophers - escapes change. This content (essence) is first of all the human being, always similar to himself, through his faculties, his basic needs, his indestructible tendencies: the stable part of his nature, accentuated by heredity, education, the spirit of imitation and habit, is the principal one. All past generations have pursued happiness and pleasure and shunned suffering, worked and played, laughed and cried, loved and hated, invented and imitated, commanded and obeyed, as ours and future generations will be like the previous ones. The spirit of man, on the other hand, cannot shirk the immutable principles of metaphysics, logic, law and morals, the laws of nature." ${ }^{59}$ This excerpt confirms

59 VLIETINCK Edward, "La philosophie de l'histoire”, in Revue néo-scolastique de philosophie, 25e année, n. 97, 1923, pp. 85-95; https://www.persee.fr/doc/phlou_0776-555x_1923_num_25_97_2334 (01.04.2021). 
our remarks according to which human nature is subject to a requirement of confirmation which is related to happiness or simply security. The idea of eternal restart marks the reality of necessary permanence of this state which must be so confirmed. Since the human being cannot escape the laws of nature, he is simply compelled to seek the best means by which he would confirm them. So it is clear that individuals cannot stop in this process until they have discovered this order of means.

However, before it is discovered, knowledge of the order of human security can allow us to envisage the potential of a form or formulation of a political order to correspond to the order of natural means through a prospective analysis of its results. That said, this form should materialize to assess its real results.

\section{CONCLUSION}

We undertook to verify human security, as the final cause of political society. It was precisely a question of verifying that human security is the foundation and the finality of political society. This was done through the premise of the Man's political animality. This has been legitimized by three natural realities: the need for individual conservation, the multitude of human beings, and the dependence on natural resources. These natural demands mean that the political animality of man is a natural nature and a cultural nature. The Natural nature refers to the adequacy between the substance of the order of human security in itself and the experience of man. The substance of the order in itself means that the order is already a reality, a state of affairs, a state of functioning that must be confirmed the way it is and no longer to be realized. Human experience conforms to this through the natural institution of family, that is to say, man and woman, who, naturally inclined to get closer for the needs of reproduction, make children. Family is not the result of some kind of experiential process but is lived naturally. This institution gives an account of the unity of its members for the purpose of jointly pursuing their conservation or simply the confirmation of the essential order of their nature which is human security. Thus by Family, the Aristotelian postulate of the human political animality is confirmed as a natural nature. But that is not enough because Man does not always master the order of natural means by which he is called to preserve himself according to the three natural requirements declined. He discovers them by learning, what confirms the cultural nature of his political animality. By this nature, man discovers or educates himself through an experimentation process of the best natural form or formulation of organization by which he conserves himself harmoniously with his fellows. Under the foundation and in pursuit of the confirmation purpose of his natural order of security, he progressively understands that the relations with his fellow men are formalized in a framework larger than the natural family and in a way which necessarily includes each individual subject to the same natural tendency. Thus, from an essentialist point of view, political society presents itself as this agreement, this understanding, this organization, this order whose adequate substance is assessed through the practical consequences of its formulations. Thus, when only one of the contracting parties fails to find his account in the form of the agreement, it is clear that it must be improved because each one, being subject to the same natural imperative, there is a natural formulation of this order by which everyone finds an 
advantageous possibility of conservation. As long as man has not reached it, he will remain subject to the historical process of experimentation. Ultimately, it will be a process of conformation of the finalized and finalitarian orders embodied by human security or else an elevation of the cultural nature of the human political animality to the level of the natural nature of this political animality, in order to confirm the adequacy between the essential order of human security in itself and the Man's life.

\section{REFERENCES}

ABEL Donald, Theories of human nature: Classical and contemporary readings, McgrawHill, New York, 1992.

ACHARYA Amitav, “Human Security: East versus West”, International Journal, vol. 56, n. 3, 2001, pp. 442-460.

ALFORD Fred, Narrative, Nature, and the Natural Law. From Aquinas to International Human Rights, Palgrave Macmillan, New York, 2010.

ATKINS Philip, "Essential vs. Accidental Properties", Stanford Encyclopedia of Philosophy, First published Tuesday April 29, 2008; substantive revision Monday April 18, 2016, https://plato.stanford.edu/entries/ essential-accidental (26.03.2021).

AXWORTHY Lloyd, "Human Security and Global Governance: Putting People First”, Global Governance, vol. 22, 1, 2001.

BARTH Hans, The Idea of Order, Contributions to a Philosophy of Politics, D. Reidel Publishing Company, Dordrecht-Holland, 1960.

BAUER Sébastien, GERBIER Laurent, "Famille", in CNRS (éd.), Grand Dictionnaire de la Philosophie, Larousse, Paris, 2003, pp. 1236-1237.

CENTRE NATIONAL DE LA RECHERCHE SCIENTIFIQUE (CNRTL), Dictionnaire sur PC Ortolang du Centre National de la Recherche Scientifique, comprenant les dictionnaires de l'Académie française jusqu’à la 9ème édition, http://www.cnrtl.fr (31.03.2021).

CHARRAK André, “Culture”, Grand Dictionnaire de la Philosophie, Larousse, Paris, 2003, p. 691.

CHENET François Xavier, "KANT, Philosophie pratique, Métaphysique des mœurs, Critique de la raison pratique”, Philopsis, éditions numériques, 2008, http://www.philopsis.fr (26.03.2021).

CICERON, La république, 1er siècle av. J.C., Livre III, \$33, trad. BRÉGUET Esther, Gallimard, 1994

COMMISSION ON HUMAN SECURITY, Human Security Now: Final Report, New York, Commission on Human Security, 2003.

COURNARI Laurent, "Aristote, Commentaire du livre IV des Politiques", Philopsis, éditions numérique, http:// www.philopsis.fr (31.03.2021).

DELEUZE Gilles, GUATTARI Felix, L'anti-CEdipe, Minuit, Paris, 1972.

ELLIS Brian, The Philosophy of Nature, A Guide to the New Essentialism, Acumen Publishing Limited, Chesham, 2002.

ESTRADA-TANCK Elena Dorothy, Human Security and Human Rights under International Law: Crossroads and Possibilities, European University Institute, 2010, http://www.operationspaix.net/ DATA/DOCUMENT (26.03.2021).

FINNIS John, "Natural law Theories ", The Stanford Encyclopedia, Metaphysics Research Lab, Stanford University, https://plato.standford.edu/archives/sum2020/entries/natural-law-theories/ (31.03.2021). 
FRIEDRICH Carl Joachim (Ed.), The Philosophy of Kant: Moral and Political Writings, New York, The Modem Library, 1949.

FUKUDA-PARR Sakiko, MESSINEO Carol, Human Security: A critical review of the literature, Centre for Research on Peace and Development, Working Paper n. 11, KU Leuven, January, 2012.

HOBBES Thomas, Léviathan. Traité de la matière, de la forme et du pouvoir de la république ecclésiastique et civile, 1651, traduit de l'anglais par FOLLIOT Philippe à partir de HOBBES Thomas of Malmesbury, Leviathan or the Matter, Forme and Power of A Commonwealth Ecclesiastical and civil, London, Printed for Andrew Crooke, 1651, Chicoutimi, Québec, janvier 2004.

HUMAN SECURITY NETWORK, http://www.humansecuritynetwork.org/network-f.php (26.03.2021)

KANT Immanuel, The Doctrine of Virtue, trans. of GREGOR Mary, New York, Harper Torchbooks, 1964.

KHONG Yuen Foong, "Human Security: A Shotgun Approach to Alleviating Human Misery?", Global Governance, vol. 7, 3 July-September 2001, pp. 231-236.

LEANING Jennifer, ARIE Sam, Human Security: A Framework for Assessment in Conflict and Transition, Prepared for US AID, Tulane Complex Emergency Response and Transition Initiative (CERTI), Tulane University. December 2000.

LEVI-STRAUSS Claude, Les structures élémentaires de la parenté, PUF, Paris, 1949.

LIOTTA Peter Hearns, OWEN Taylor, "Why Human Security?" in The Whitehead Journal of Diplomacy and International Relations, vol 7, 1, Winter/Spring 2006, pp. 37-54.

LOCKE John, Traité du gouvernement civil, 1690, trad. française de MAZEL David, 1795 à partir de la 5 ème édition de Londres publiée en 1728, Chicoutimi, Québec, 2002.

NATIONS UNIES ASSEMBLEE GENERALE, Résolution adoptée par l'Assemblée générale le 10 septembre 2012 [sans renvoi à une grande commission A/66/L.55/Rev.1 et Add.1)] A/RES/66/290 66/290, Suite donnée au paragraphe 143 sur la sécurité humaine du Document final du Sommet mondial de 2005, 25 octobre 2012

NEF Jorge, "Human Security, Mutual Vulnerability and Sustainable Development: A Critical View", The Whitehead Journal of Diplomacy and International Relations, vol. 7, n. 1, Winter-Spring 2006, pp. 55-73.

NIETZSCHE Friedrich, La volonté de puissance, 2 tomes, Gallimard, Paris, 1995.

OURLIAC Paul, GAZZANIGA Jean-Louis, Histoire du droit privé français, II, 4, Albin Michel, Paris, 1985.

OWEN Taylor, "Human security. Conflict and Consensus: Colloquium Remarks and Proposal for a ThresholdBased definition", Security Dialogue, vol. 35, n. 3, September 2004, pp. 373-387.

PROGRAMME DES NATIONS UNIES POUR LE DEVELOPPEMENT, Rapport mondial sur le développement humain, Paris, Economica, 1994

RIMBOUX Elsa, "Politique", Grand Dictionnaire de la Philosophie, Edition numérique, Larousse, Bibliothèque Nationale de France, pour la bibliothèque numérique Gallica, 2003, pp. 2397-2399.

ROBERTSON David, The Routledge Dictionary of Politics, 3rd Ed., Taylor and Francis Group, Routledge USA and Canada, New Fetter Lane, London, New York, 2004.

ROUSSEAU Jean-Jacques, Du contrat social ou Principes du droit politique, 1762, Document produit en version numérique par TREMBLAY Jean-Marie, Les classiques des sciences sociales, Paris, 1963.

RUSSELL Bertrand, A History of Western Philosophy and its Connection with Political and Social Circumstances from the Earliest Times to the Present Day, Simon and Schuster, New York, 1945. 
SAINT-HILAIRE Jules Barthelemy, La Politique d'Aristote, Traduite en Français d'après le Texte Collationné sur Les Manuscrits et les Éditions Principales, Troisième Édition, Revue et Corrigée, Paris, Librairie Philosophique de Ladrange, 1874.

SCRUTON Roger, "Politics", The Palgrave Macmillan Dictionary of Political Thought, 3rd edition, Palgrave Macmillan, New York, 2007.

TANZELLA-NITTI Giuseppe, “The Aristotelian-Thomistic Concept of Nature and the Contemporary Debate on the Meaning of Natural Laws", Acta Philosophica, n. 6, 1997.

TRICAUD François, "Hobbes et Locke: convergences et divergences", in: XVII-XVIII. Bulletin de la société d'études angloaméricaines, des XVIIe et XVIIIe siècle, n. 25, 1987, http://www.persee.fr/doc/ xvii_0291-3798_1987_num_25_1_1120 (01.04.2021).

UNITED NATIONS GENERAL ASSEMBLY, Resolution adopted by the General Assembly on 10 September 2012 [without reference to a Main Committee (A/66/L.55/Rev.1 and Add.1)], Follow-up to paragraph 143 on human security of the 2005 World Summit Outcome, A/RES/66/290 66/290, 25 October 2012

VLIETINCK Edward, "La philosophie de l'histoire”, in Revue néo-scolastique de philosophie, 25区 année, n. 97, 1923, pp. 85-95; https://www.persee.fr/doc/phlou_0776-555x_1923_num_25_97_2334 (01.04.2021). 